\title{
The Unequal Distribution of Child Poverty: Highest Rates among Young Blacks and Children of Single Mothers in Rural America
}

\author{
MARYBETH J. MATTINGLY AND JESSICA A. BEAN
}

$\mathrm{T}$ his brief reports poverty rates by race and family structure for all children and by place and region for young children (those under age 6). ${ }^{1}$ We use the U.S. Office of Management and Budget income thresholds. In 2009 , the poverty line for a family of four (two adults, two children) was $\$ 21,756 .{ }^{2}$

For all children, especially the youngest, the highest rates of poverty are among blacks, followed by Hispanics and whites (see Table 1). ${ }^{3}$ This pattern persists across urban, suburban, and rural places, with estimated rates for children under age 18 as high as 48.9 percent for rural black children and 36.6 percent for rural Hispanic children. The rates for rural white children are significantly lower at 18.5 percentalthough still higher than national averages.

Although all children suffer consequences of being poor, young children are particularly vulnerable, and the consequences of early poverty ripple through the life cycle in the form of poorer life-long health, fewer years of completed schooling, and other disadvantages. ${ }^{4}$ Our analyses reveal that poverty rates are typically higher among the very young. Further, young white, black, and Hispanic rural children are more often poorer than their urban and suburban counterparts. More than one in five young rural white children are poor, as are more than two in five young rural Hispanic children; however, this affects a staggering one in two young rural black children.

According to U.S. Census Bureau data, nearly 17 million children live in single-mother homes. Indeed, 50.2 percent of black children, 24.9 percent of Hispanic children, and 17.7 percent of white children are living with only their mothers. ${ }^{5}$ In all place types, across all regions, single-mother families have dramatically higher poverty rates (40 percent) than married couples with children (8 percent) (see Table 2 ). There are also important local and regional distinctions. Nearly one in two rural single-mother families are poor, and rates are

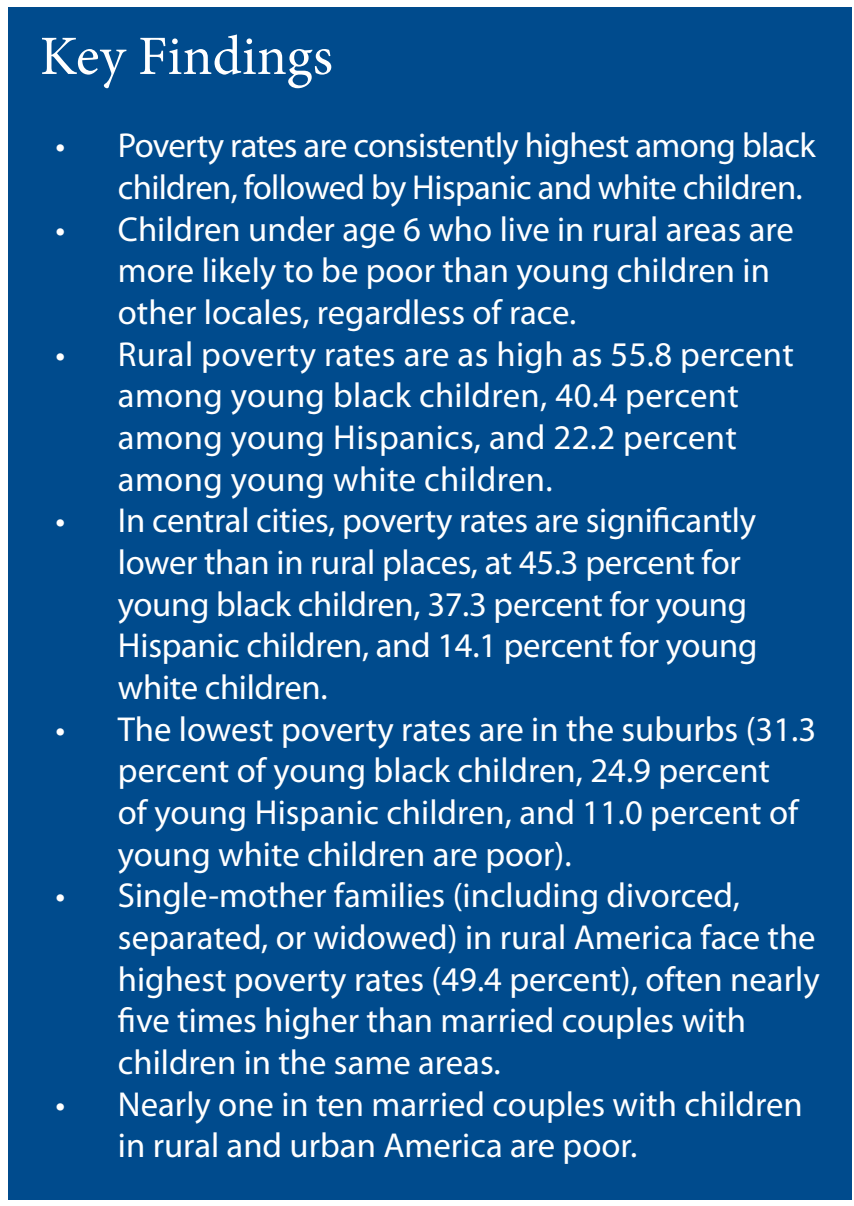

highest in the rural South, where more than 54 percent of such families live in poverty. Poverty among single-mother families is high in the Midwest as well, where rates approach 50 percent in urban and rural areas. For both family types, poverty is lowest in the suburban Northeast, although the 
TABLE 1. Child POVERTY BY PLACE TYPE AND REgion IN 2009a

\begin{tabular}{|c|c|c|c|c|c|c|c|c|}
\hline & \multicolumn{2}{|c|}{ Total Population } & \multicolumn{2}{|c|}{ Central City } & \multicolumn{2}{|c|}{ Suburban } & \multicolumn{2}{|c|}{ Rural } \\
\hline & $\begin{array}{l}\text { Percent } \\
\text { estimate }\end{array}$ & $\begin{array}{c}\text { Margin of } \\
\text { error }\end{array}$ & $\begin{array}{l}\text { Percent } \\
\text { estimate }\end{array}$ & $\begin{array}{l}\text { Margin of } \\
\text { error }\end{array}$ & $\begin{array}{c}\text { Percent } \\
\text { estimate }\end{array}$ & $\begin{array}{l}\text { Margin of } \\
\text { error }\end{array}$ & $\begin{array}{l}\text { Percent } \\
\text { estimate }\end{array}$ & $\begin{array}{c}\text { Margin of } \\
\text { error }\end{array}$ \\
\hline \multicolumn{9}{|c|}{ Children Under 6} \\
\hline White & 14.0 & $+/-0.24$ & 14.1 & $+/-0.53$ & 11.0 & $+/-0.27$ & 22.2 & $+/-0.56$ \\
\hline Black & 41.0 & $+/-0.51$ & 45.3 & $+/-0.77$ & 31.3 & $+/-2.79$ & 55.8 & $+/-1.80$ \\
\hline Hispanic & 33.6 & $+/-0.41$ & 37.3 & $+/-0.62$ & 24.9 & $+/-0.58$ & 40.4 & $+/-1.52$ \\
\hline \multicolumn{9}{|c|}{ ChILdREN UNDER 18} \\
\hline \multicolumn{9}{|l|}{ White } \\
\hline United States & 12.0 & $+/-0.12$ & 12.6 & $+/-0.29$ & 9.4 & $+/-0.27$ & 18.5 & $+/-0.29$ \\
\hline Northeast & 9.7 & $+/-0.23$ & 14.8 & $+/-0.78$ & 7.4 & $+/-0.25$ & 16.4 & $+/-0.65$ \\
\hline Midwest & 13.1 & $+/-0.22$ & 15.6 & $+/-0.61$ & 10.0 & $+/-0.26$ & 20.0 & $+/-0.45$ \\
\hline South & 13.0 & $+/-0.21$ & 11.2 & $+/-0.47$ & 10.6 & $+/-0.25$ & 20.6 & $+/-0.48$ \\
\hline West & 10.5 & $+/-0.26$ & 10.8 & $+/-0.44$ & 9.2 & $+/-0.32$ & 15.3 & $+/-0.73$ \\
\hline \multicolumn{9}{|l|}{ Black } \\
\hline United States & 36.3 & $+/-0.34$ & 41.0 & $+/-0.97$ & 27.0 & $+/-0.53$ & 48.9 & $+/-1.03$ \\
\hline Northeast & 31.1 & $+/-0.78$ & 34.9 & $+/-1.06$ & 24.5 & $+/-1.31$ & 25.2 & $+/-5.63$ \\
\hline Midwest & 44.1 & $+/-0.74$ & 49.7 & $+/-0.90$ & 32.0 & $+/-1.38$ & 39.9 & $+/-3.65$ \\
\hline South & 36.2 & $+/-0.45$ & 40.9 & $+/-0.77$ & 26.6 & $+/-0.65$ & 50.3 & $+/-1.08$ \\
\hline West & 30.3 & $+/-1.16$ & 33.2 & $+/-1.52$ & 26.6 & $+/-1.88$ & 26.4 & $+/-7.70$ \\
\hline \multicolumn{9}{|l|}{ Hispanic } \\
\hline United States & 30.8 & $+/-0.25$ & 34.8 & $+/-0.37$ & 25.1 & $+/-0.39$ & 36.6 & $+/-0.88$ \\
\hline Northeast & 32.1 & $+/-0.72$ & 39.7 & $+/-1.00$ & 23.0 & $+/-1.01$ & 30.3 & $+/-8.85$ \\
\hline Midwest & 30.5 & $+/-0.76$ & 36.5 & $+/-1.25$ & 22.8 & $+/-1.18$ & 34.3 & $+/-1.95$ \\
\hline South & 33.1 & $+/-0.42$ & 36.3 & $+/-0.72$ & 28.3 & $+/-0.53$ & 42.2 & $+/-1.94$ \\
\hline West & 28.7 & $+/-0.76$ & 31.6 & $+/-0.57$ & 25.4 & $+/-0.92$ & 31.1 & $+/-3.43$ \\
\hline
\end{tabular}

a. Unit of analysis is children.

b. Levels of urbanization are defined as follows: rural consists of ACS geographic components "not in metropolitan or micropolitan statistical area" and "in micropolitan statistical area," suburban includes "in metropolitcan statistical area—not in principal city," and central city includes "in metropolitan stastical area-in principal city."

c. Data are based on 2009 ACS estimates.

d. Percentage points and margins of error are based on rounded percentages and may differ slightly from those that would be obtained using unrounded figures.

rate there for single mothers is 29.9 percent, nearly ten times the rate for married couples ( 3 percent).

Young children face high rates of poverty in America, especially if they are children of color living in rural areas or in lone-parent families. Research has shown that access to social programs, such as Women, Infants, and Children's (WIC), Medicaid, and home visiting can limit some of the negative effects of poverty. ${ }^{6}$ In addition, certain educational programs, such as Early Head Start, are shown to have positive effects on child development, ${ }^{7}$ which could set children up for long-term educational success. For children in single-mother homes, focusing on increased compliance with child support orders may be critical for lowering poverty. ${ }^{8}$ Overall, access to these types of programs should be improved, particularly for families in rural areas, to provide support for these very young children who are already facing a challenging future. 
TAble 2. Poverty By family Structure, Place type, AND Region in 2009 ${ }^{a}$

\begin{tabular}{|c|c|c|c|c|c|c|c|c|}
\hline & \multicolumn{2}{|c|}{ Total Population } & \multicolumn{2}{|c|}{ Central City } & \multicolumn{2}{|c|}{ SUBURBAN } & \multicolumn{2}{|c|}{ RURAL } \\
\hline & $\begin{array}{l}\text { Percent } \\
\text { estimate }\end{array}$ & $\begin{array}{c}\text { Margin of } \\
\text { error }\end{array}$ & $\begin{array}{l}\text { Percent } \\
\text { estimate }\end{array}$ & $\begin{array}{c}\text { Margin of } \\
\text { error }\end{array}$ & $\begin{array}{l}\text { Percent } \\
\text { estimate }\end{array}$ & $\begin{array}{c}\text { Margin of } \\
\text { error }\end{array}$ & $\begin{array}{l}\text { Percent } \\
\text { estimate }\end{array}$ & $\begin{array}{c}\text { Margin of } \\
\text { error }\end{array}$ \\
\hline \multicolumn{9}{|c|}{ MARRIED COUPLES WITH CHILDREN } \\
\hline United States & 7.5 & $+/-0.11$ & 10.0 & $+/-0.27$ & 5.5 & $+/-0.14$ & 9.9 & $+/-0.34$ \\
\hline Northeast & 5.0 & $+/-0.26$ & 10.1 & $+/-0.73$ & 3.1 & $+/-0.22$ & 6.5 & $+/-0.56$ \\
\hline Midwest & 6.5 & $+/-0.20$ & 9.6 & $+/-0.51$ & 4.4 & $+/-0.22$ & 8.6 & $+/-0.52$ \\
\hline South & 8.5 & $+/-0.20$ & 10.3 & $+/-0.48$ & 6.5 & $+/-0.26$ & 12.0 & $+/-0.57$ \\
\hline West & 8.6 & $+/-0.25$ & 9.9 & $+/-0.40$ & 7.4 & $+/-0.33$ & 9.7 & $+/-0.87$ \\
\hline \multicolumn{9}{|l|}{ SINGLE MOTHERS } \\
\hline United States & 40.0 & $+/-0.36$ & 43.8 & $+/-0.58$ & 33.2 & $+/-0.49$ & 49.4 & $+/-0.87$ \\
\hline Northeast & 36.6 & $+/-0.65$ & 43.6 & $+/-0.84$ & 29.9 & $+/-1.11$ & 39.8 & $+/-2.05$ \\
\hline Midwest & 42.2 & $+/-0.72$ & 48.3 & $+/-1.37$ & 34.1 & $+/-1.14$ & 46.8 & $+/-1.42$ \\
\hline South & 42.1 & $+/-0.53$ & 44.7 & $+/-0.68$ & 34.5 & $+/-0.68$ & 54.0 & $+/-1.38$ \\
\hline West & 36.4 & $+/-0.80$ & 38.2 & $+/-1.13$ & 33.0 & $+/-1.07$ & 43.9 & $+/-2.57$ \\
\hline
\end{tabular}

a. Unit of analysis is families.

b. Levels of urbanization are defined as follows: rural consists of ACS geographic components "not in metropolitan or micropolitan statistical area" and "in micropolitan statistical area," suburban includes "in metropolitcan statistical area-not in principal city," and central city includes "in metropolitan stastical area-in principal city."

c. Data are based on 2009 ACS estimates.

d. Percentage points and margins of error are based on rounded percentages and may differ slightly from those that would be obtained using unrounded figures.

\section{Data}

This analysis is based on U.S. Census Bureau estimates from the 2009 American Community Survey released on September 28, 2010. ${ }^{9}$ Tables were produced by aggregating information from detailed tables available on American FactFinder (http://factfinder.census.gov/home/saff/main. html?_lang=en). These estimates are meant to give perspective on child poverty, but because they are based on survey data, caution must be used in comparing across years or places, as the margin of error may indicate that seemingly disparate numbers fall within sampling error. ${ }^{10}$ Differences highlighted in this brief are statistically significant at the 5 percent level.

\section{E N D N O T E S}

1. The American Community Survey (ACS) data released in September 2010 allow nuanced analyses of child poverty.

2. See http://www.census.gov/hhes/www/poverty/about/ overview/measure.html, and "U.S. Census Bureau, September 2010 Poverty: 2009 Highlights.”

3. Sampling size limitations preclude racial/ethnic breakdowns more refined than the three groups (white, black, Hispanic) we use.

4. See Robert H. Bradley et al., "The Home Environments of Children in the United States, Part I: Variations by Age, Ethnicity, and Poverty Status," Child Development 72 (2001): 1844-1886; Jeanne Brooks-Gunn and Greg. J. Duncan, “The Effects of Poverty on Children," The Future of Children 7 (1997): 55-71; Vonnie C. McLoyd, "Socioeconomic Disadvantages and Child Development," American Psychologist 53 (1998): 185-204; Anne Case, Angela Fertig, and Christina Paxson, "The Lasting Impact of Childhood Health and Circumstance," Journal of Health Economics 24 (2005): 365-389.

5. See U.S. Census Bureau, “America's Family and Living Arrangements: 2009, Current Population Survey, Annual Social and Economic Supplement, Table C9," available at www.census.gov/population/www/socdemo/hh-fam/cps2009.html. 
6. See Caroline Ratcliffe and Signe-Mary McKernan, "Help Children Born into Poverty" (Washington, DC: The Urban Institute, 2010).

7. John M. Love et al., "Making a Difference in the Lives of Infants and Toddlers and Their Families: The Impacts of Early Head Start" (Princeton, NJ: Mathematica Policy Research, 2009).

8. Kristin Anderson Moore et al. "Children in Poverty: Trends, Consequences, and Policy Options," Research Brief No. 2009-11 (Washington, DC: Child Trends, 2009).

9. For more information, see http://factfinder.census.gov/servlet/DTGeoSearchByListServlet?ds_ name $=$ ACS_2007_3YR_G00_\&_lang=en\&_ ts $=268570514748$.

10. Refer to the U.S. Census Bureau's published tables for detailed margins of error.

\section{ABOUT THE AUTHORS}

Marybeth J. Mattingly is director of research on vulnerable families at the Carsey Institute and a research assistant professor of sociology at the University of New Hampshire (beth.mattingly@unh.edu).

Jessica A. Bean is a vulnerable families research associate at the Carsey Institute (jessica.bean@unh.edu).

\section{A C K N O W LE D GMEN T S}

The authors thank Michelle Stransky and Sara Dillingham, students working at the Carsey Institute, for their assistance in preparing this brief; Mil Duncan, Kenneth Johnson, Terri Rippett, and Amy Sterndale at the Carsey Institute; Barbara Ray at The Hired Pen; and Leif Jensen and Diane McLaughlin at Pennsylvania State University for comments and suggestions.

\section{$\triangle$ UNIVERSITY -}

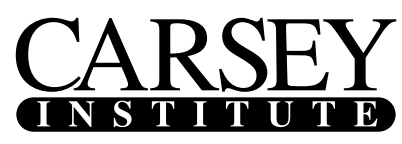

Building knowledge for families and communities

The Carsey Institute conducts policy research on vulnerable children, youth, and families and on sustainable community development. We give policy makers and practitioners timely, independent resources to effect change in their communities.

This work was supported by the Annie E. Casey Foundation, the W. K. Kellogg Foundation, and an anonymous donor.

Huddleston Hall

73 Main Street

Durham, NH 03824

$(603) 862-2821$

www.carseyinstitute.unh.edu 